\title{
Anti-Interleukin 6 Monoclonal Antibody ALD518
}

National Cancer Institute

\section{Source}

National Cancer Institute. Anti-Interleukin 6 Monoclonal Antibody ALD518. NCI

Thesaurus. Code C82359.

A humanized monoclonal antibody directed ag ainst the pro-inflammatory cytokine interleukin-6 (II-6) with potential immunomodulating activity. Upon administration, antiinterleukin 6 monoclonal antibody ALD518 binds to and blocks the activity of IL-6, which may mitigate the catabolic effects of IL-6. 